\title{
WISATA BUDAYA DAN KESEJAHTERAAN
}

\author{
Lalu Hairurrozi \\ Mahasiswa Jurusan Pengembangan Masyarakat Islam UIN Mataram \\ Email: lalurozi9@gmail.com
}

\begin{abstract}
Abstrak:
keterlibatan sektor pariwisata dalam panggung dunia kehidupan manusia diseluruh dunia memiliki dampak besar bagi peradaban dan perubahan dinamika kehidupan dari semua asfek kegiatan sosialisme, wisata yang telah menggarap dan melahap habis semua bidang kehidupan dalam lingkungan manusia yang relative berubah-ubah seiring perputaran waktu dan rotasi bumi, sehingga wisata bukan hanya sebagai ajang rekreasi, menikmati keindahan hanya untuk mencari ketenangan dan kesenangan diri, namun juga bisa sebagai ajang pembelajaran terhadap nilai, norma dan pola kehidupan masyarakat yang berbeda-beda dalam konteks sosial budayanya. Wisata sebelumnya hanya dikenal sebagai tempat dimana terdapat keindahan-keindahan yang disajikan oleh alam untuk dinikmati para pengunjung, tetapi dalam tulisan ini penulis ingin merubah paradigm itu semua, bahwa berwisata tidak hanya sebagai ajang mencari kesenangan, melainkan juga dapat sebagai ajang penambahan wawasan dan mengenal berbagai budaya diseluruh dunia berdasarkan keterlibatan sektor pariwisata sebagai kemasan baru budaya tanpa merusak ciri dan citra keaslian buday itu sendiri.

Dalam tulisan kali ini ingin mengungkap dan memaparkan tentang manfaat sektor pariwisata dari hasil garapannya dalam dunia kebudayaan sehingga mewujudkan jelmaan baru menjadi "wisata budaya" yang lebih ditonjolkan pada sejauh mana tingkat kesejahteraan masyarakat dapat terealisasikan bedasarkan keberadaan wisata budaya Dusun Sade Lombok Tengah melalui sistem hasil kajian kontribusi nyata.
\end{abstract}

Keywords: Kesejahteraan, Wisata, Budaya, dan Kontribusi 


\section{A. Pendahuluan}

Manusia pada umumnya menginginkan kehidupan yang layak dan lebih baik dari sebelumnya, yakni dengan melakukan berbagai macam upaya dan usaha dalam mencapai keinginan tersebut. Baik layak secara rohani maupun jasmani, ekonomi ataupun sosial budaya kemasyarakatan, guna terpenuhinya segala bentuk kebutuhan pribadi, keluarga, serta masyarakat, sehingga kesejahteraan sosial dalam hidup dapat diwujudkan. Dalam hal pencapaian sebuah kesejahteraan di lingkungan masyarakat, kali ini penulis mengartikan sebagai tujuan (goal) dengan melewati banyak akses yang dapat di pilih, dengan kata lain, kesejahteraan dapat diwujudkan melalui berbagai jalan yang dianggap layak dan sesuai dengan apa yang dibutuhkan, serta diyakini efektif dan efisien sebagai langkah pencapaian yang tepat. Sama halnya dengan tulisan ini, yang ingin mendobrak pemahaman bahwa kesejahteraan masyarakat juga bisa terwujud melalui keberadaan sektor pariwisata sebagai sebuah kontribusi nyata dalam kehidupan masyarakat.

Lumerahnya kata wisata di telinga masyarakat mengartikan sebagai aktivitas rekreasi, jalan-jalan sambil menikmati keindahan alam (panorama) dan identik dengan penghamburan uang hanya untuk mendapatkan kesenangan dan ketenangan diri. Itu semua tidak terlepas berdasarkan hasil interpretasi penulis dari buku Pengantar Pemasaran Pariwisata yang mengutip Undang-Undang Republik Indonesia Nomor 10 Tahun 2009 tentang kepariwisataan pada Bab I pasal 1 point (1) menjelaskan bahwa; Wisata adalah kegiatan perjalanan yang dilakukan oleh sebagian atau sekelompok orang dengan mengunjungi tempat tertentu untuk tujuan rekreasi, pengembangan pribadi, atau mempelajari keunikan daya tarik wisata yang dikunjungi dalam waktu sementara. ${ }^{1}$ hlm. 31 .

${ }^{1}$ M. Liga Suryadana \& Vanny Octavia, Pengantar Pemasaran Pariwisata, (Bandung; Alfabeta, 2015), 
Tentu saja hal ini yang melatarbelakangi kenapa setiap orang membutuhkan rekreasi ke tempat-tempat wisata yang ada. sebagai contoh sebut saja salah satunya pulau "Lombok". Pulau ini sering disebut sebagai pulau seribu masjid, pulau dimana masyarakat yang mendominasinya ialah ummat muslim serta terdiri dari banyaknya bangunan-bangunan tempat ibadah (masjid). Namun disamping itu pula, pulau Lombok juga dikenal sebagai pulau surga, pulau yang menyimpan sejuta keindahan dan keaneka-ragaman bahasa (language), sosial (social), dan budaya (culture) sebagai harta kekayaan yang dimiliki dan dapat dinikmati oleh semua orang.

Wisata yang memiliki berbagai jenis dan kriteria yang ikut mewarnai dunia sektor pariwisata diantaranya; Pertama Wisata Alam yang terdiri dari; Wisata Pantai (Marine tourism), Wisata Etnik (Ethnic tourism), Wisata Cagar Alam (Ecotourism), Wisata Buru, dan Wisata Agro. Kedua Wisata Sosial-Budaya yang terdiri dari; Peninggalan sejarah kepurbakalaan dan monumen, serta Museum dan fasilitas budaya lainnya ${ }^{2}$ secara umum melengkapi kebutuhan wisatawan diseluruh dunia berdasarkan potensi dari wilayahnya masing-masing. Wilayah Lombok khususnya, dari beberapa jenis dan kriteria wisata tersebut lebih banyak terdapat wisata pantai, cagar alam, etnik, dan sosial-budaya yang dapat memenuhi kebutuhan dari segi pengetahuan serta kepuasan dari setiap individu berdasarkan tingkat minat personal. Sehingga kalau diterawang dari aspek ketersediaan tempat wisata yang dapat dikategorikan cukup banyak di Lombok secara sempit, maka sudah tidak diragukan lagi bahwa ber-wisata sudah menjadi budaya dalam aktivitas kehidupan sehari-hari. Secara singkat dan tidak langsung budaya ber-wisata bagi masyarakat sudah mulai muncul di tubuh era milenial.

${ }^{2}$ Ibid., hlm. 32 
Jika budaya ber-wisata telah menggarap dan menjadi bagian dalam tubuh masyarakat bahkan menjadi kebutuhan dalam rangkaian proses aktivitas kehidupan, mungkin ini sudah terdengar biasa dan wajar dialami oleh setiap personal, lantas bagaimana dengan budaya yang di anut oleh etnis/masyarakat suku sebagai pegangan dan tuntunan hidup yang diyakini dan bersifat sakral, kini dijadikan sebagai salah satu destinasi wisata atau dapat dikenal dengan sebutan "wisata budaya". Dalam konteks inilah menjadi dasar pemikiran penulis bahwa sektor pariwisata telah menggarap semua lini kehidupan yang bersifat pleksible dan cocok terhadap semua jenis bidang kehidupan termasuk budaya. Budaya kita ketahui sebagai sebuah hasil cipta cinta, rasa, dan karsa yang menghasilkan bentuk material dan nonmaterial kemudian dipercayai oleh masyarakat dan dijalankan sesuai tatacara serta dilakukan secara turuntemurun, sehingga budaya memang ciptakan oleh manusia sesuai apa yang diterangkan dalam buku IImu Sosial Dan Budaya Dasar bahwa budaya mengalami perubahan dan perkembangannya sejalan dengan perkembangan manusia itu. Perkembangan tersebut dimaksudkan untuk kepentingan manusia sendiri, karena kebudayaan diciptakan oleh dan untuk manusia. ${ }^{3}$ Sehingga disamping manusia menjadi pencipta, juga berperan sebagai penganut atau lebih kerennya disebut sebagai subject sekaligus object kegiatan.

Kegiatan proses dari wisata budaya yang penulis fokuskan pada wilayah Dusun Sade Lombok Tengah sebagai objek dari pembahasan dalam tunisan ini yang akan melihat beberapa kontribusi terhadap tingkat kesejahteraan masyarakatnya, serta akan disajikan dengan peluang dan hambatan dalam pencapaian sebagai tangga awal dalam melihat mengukur seberapa jauh langkah kontribusi yang dapat diberikan

${ }^{3}$ Elly M. Setiadi, dkk, Ilmu Sosial Dan Budaya Dasar, (Jakarta: Kencana, 2008), hlm. 40. 
terhadap kesejahteraan masyarakat melalui keberadaan wisata bercirikan budaya.

\section{B. Hambatan dan peluang wisata budaya Sade dalam meningkatkan kesejahteraan masyarakat.}

Umumnya usaha dalam meraih suatu tujuan melalui berbagai cara pencapaian, tentu tidak terlepas dari beberapa macam tantangan dan dibarengi oleh peluang pada sisi lainya, yang kedua aspek ini tidak bisa dipisahkan dalam mengisi kehidupan lingkungan sosial masyarakat, seolah-olah sudah menjadi kodrat yang harus dihadapi dan dilewati dalam proses perputaran roda kehidupan, terutama bagi keberadaan destinasi wisata budaya Dusun Sade, dan bagaimana cara masyarakat lokal dalam memanfaatkan peluang sumber daya alam sebagai daya tarik kunci secara optimal untuk kesejahteraan serta mampu juga untuk menghadapi berbagai hambatan dalam pencapaian kesejahteraan tersebut antara lain:

\section{Peluang}

Ketersediaan sumber daya alam serta keunikan suatu wilayah merupakan peluang terbesar dalam pengembangan pariwisata guna pengoptimalisasi pencapaian kesejahteraan dan perbaikan taraf hidup masyarakat. Kekayaan sumber daya alam yang dimiliki suatu daerah atau tempat merupakan aset paling berharga bagi masyarakat lokal untuk bisa dimanfaatkan dalam usaha pengembangannya sebagai sebuah daya tarik bagi wisatawan. Wisata dusun Sade salah satunya, dalam usaha mencapai tingkat kesejahteraan masyarakat menggunakan sistem pengembangan pariwisata melalui pengelolaan sumber daya alam seperti budaya fisik dan non fisik, pengelolaan dan pengembangan tersebut bisa dilihat melalui; Pertama, artepak-artepak yang masih berdiri kokoh dengan citra kebudayaan fisiknya, serta non fisik seperti 
sebelumnya menampilkan budaya Gendang Beleq, Tari Petuk, Oncek, dan Presean. Melihat tingkat peminat wisata akhir-akhir ini yang semakin berkembang dan meningkat di setiap kawasan wisata yang ada di Lombok, maka wisata dusun sade berinisiatif untuk memberikan tampilan baru yang merupakan salah satu tradisi yang telah di anut sejak lama dan kini akan dimunculkan label tradisi budaya lama seperti nede hujan ke permukaan publik sektor pariwisata sebagai daya tarik baru bagi wisatawan yang ingin melihat bagaimana pelaksanaan dari setiap budaya, tradisi dan kesenian dari wisata budaya Dusun Sade. Kedua, Dari sisi letak geografisnya, wisata budaya Sade cukup strategis karena wilaya Sade sebagai merupakan salah satu bagian dari akses menuju kawasan ekonomi kreatif (KEK) yang ada di Lombok bagian selatan, sehingga memungkinkan untuk memposisikan diri untuk berperan sebagai penopang seluruh aktivitas kegiatan tersebut, dalam artinya bahwa para wisatawan akan melewati kawasan Sade sebelum sampai ke Kuta Mandalika dimana tempat aktivitas KEK sebagai lokasi inti dari persinggahan dan aktivitas tour. Maka wisata Sade berpeluang untuk melakukan kerjasama dengan berbagai perusahaan yang bergelut di bidang pariwisata dan memiliki mitra ekstern maupun intern dalam demi keberlangsungan dan eksistensi wisata dusun Sade secara berkesinambungan. Ketiga, Wisata budaya Dusun Sade juga memiliki potensi yang sangat berpengaruh besar terhadap kelangsungan hidup masyarakat lokal, karena dari sisi daya tarik wisata budaya Sade sudah memiliki potensi yang cukup untuk dinikmati oleh para pengunjung antara lain banyak menyediakan hasil kerajinan tangan masyarakat lokal yang bercirikan budaya khas yang bisa di bawa pulang oleh pengunjung, selain itu juga pengunjung bisa menikmati keindahan kawasan serta bisa mempelajari mengenai budaya Sade bagi wisatawan yang memiliki 
keinginan untuk menambah wawasan keilmuan mengenai budaya. Sehingga, usaha yang dilakukan dari sistem pariwisata ini adalah mengembangkan wisata budaya Sade sebagai alternatif dengan tujuan untuk usaha peningkatan taraf hidup masyarakat lokal atau tercapainya kesejahteraan hidup.

\section{Hambatan}

Rancangan sebuah usaha pengembangan pariwisata guna mempersiapkan bekal untuk menghadapi setiap dinamika perubahan dan tantangan zaman, sehingga muncul hasil-hasil prediksi gambaran pada masa yang akan datang, dengan mengacu kepada pertimbangan keadaan sekarang dan masa lalu. Berdasarkan hal itu, maka tersusunlah rencana yang tersusun sistematis guna untuk menghadapi hal-hal yang kemungkinan besar dapat terjadi kapan saja. Sama halnya dengan usaha masyarakat suku sasak Sade dalam upaya meningkatkan kesejahteraan hidup melalui keberadaan destinasi di wilayahnya (wisata budaya), dengan bercirikan budaya sebagai pemikat daya tarik pengunjung serta keaslian desain arsitekturnya, kesenian, kerajinan dan kearifan lokal lainnya.

Namun, terkadang dalam upaya mempertahankan berbagai bentuk artepak (budaya fisik) dan budaya non fisik sangat merumitkan, disamping itu dalam konteks wisata budaya Sade, bangunan-banguna arsitektur budaya yang masih unik dan digunakan memang menjadi salah satu item penarik minat pengunjung di samping adanya budaya non fisik. Tetapi di sisi lain, hal ini juga menjadi hambatan. Seperti ciri bangunan budaya Sade sebagai contoh dari budaya fisik yang setiap banguannya harus beratapkan alang-alang (ere) dan tanaman alangalang sulit untuk didapatkan, selain itu juga walaupun tanaman ini ada, 
harganya sangatlah mahal dan cara menganyampun tidaklah mudah, sebab motif unik itulah yang mencirikan khas yang dipelihara hingga bisa ditemukan dan dilihat oleh generasi-generasi di bawahnya, menjadi salah satu hambatan dalam upaya pengembangan dan pemeliharaan keberadaan budaya secara berkelanjutan. Selanjutnya dari segi budaya non fisiknya, mempertahankan nilai, norma dan etika budaya dalam diri pemuda dan masyarakat suku sasak Sade, agar tetap selalu menumbuhkan rasa cinta terhadap budaya sendiri dan mau mempertahankan di segala situasi dan kondisi dinamika perubahan zaman pun ikut serta sebagai tantangan yang mau tidak mau harus dihadapi.

Kemunculan era digital ini menjadi kehawatiran masyarakat terutama pada generasi-generasi penerusnya, yang dimana pada zaman tersebut identik dengan kehidupan yang serba instan dan kebarat-baratan (westernisasi), sehingga ini yang bisa menyebabkan semakin terkikisnya citra budaya yang ada di Sade khususnya. Maka dari itu, di anggap penting menjadi antisipasi masyarakat terhadap halhal semacam itu supaya tidak terjadi, hingga kebudayaan dan hasil peninggalan nenek moyang terdahulu bisa tetap hidup di tengahtengah masyarakat sebagai tuntunan hidup dalam ber-etika serta bertingkahlaku dan memberikan manfaat bagi semua orang terutama untuk meningkatkan taraf hidup masyarakat suku sasak Sade melalui alternatif keberadaan sektor pengembangan pariwisata.

\section{Kontribusi wisata budaya untuk meningkatkan kesejahteraan masyarakat.}

Diakui bahwa sumbangan sektor pariwisata terhadap perolehan devisa dan penciptaan lapangan kerja secara makro cukup signifikan. 
Sumbangan pariwisata yang secara signifikan pada perkembangan ekonomi suatu negara atau daerah tampak dalam bentuk perluasan peluang kerja, peningkatan pendapatan (devisa) dan pemerataan pembangunan spasial. ${ }^{4}$ Secara mikro dalam garapan wilayah yang lebih kecil mengenai aspek peluang kerja, pembangunan serta peningkatan pendapatan dalam skala kecil juga dialami oleh masyarakat di kawasan wisata budaya dusun Sade, ini dapat terlihat dari banyaknya perubahan-perubahan yang dialami oleh masyarakat Sade semenjak wilayah tersebut diresmikan menjadi salah satu destinasi di Lombok Tengah bagian selatan, baik perubahan itu dilihat dari segi pendapatan ekonomi, kehidupan sosial, cara berinteraksi, peluang kerja dan lain sebagainya sudah mulai dirasakan oleh masyarakat sebagai efek dari adanya sistem lembaga kepariwisataan yang hidup di tengah-tengah masyarakat suku sasak Sade.

Perubahan-perubahan inilah yang dikategorikan sebagai sebuah kontribusi atau dampak yang dihasilkan oleh keberadaan sektor pariwisata, yang secara langsung bersentuhan dan dirasakan oleh masyarakat lokal sebagai aktivitas dalam usaha memenuhi segala bentuk kebutuhan dan hasil upaya dalam meraih kesejahteraan hidup yang tidak hanya terpaku dengan ekonomi semata, sebab kesejahteraan tidak hanya menggarap bidang perekonomian atau material saja, melainkan spiritual dan sosial juga seperti apa yang tertera dalam buku Pekerja Sosial \& Kesejahteraan sosial yang mengutip Undang-undang no 11 tahun 2009, pasal 1 ayat 1 bahwa, "kesejahteraan sosial adalah kondisi terpenuhinya kebutuhan material, spiritual dan sosial warga negara agar dapat hidup layak dan mampu

\footnotetext{
${ }^{4}$ Janianton Damanik, Pariwisata Indonesia Antara Peluang \& Tantangan. (Yogyakarta: Pustaka Pelajar), hlm. 3-4
} 
mengembangkan diri, sehingga dapat melaksanakan fungsi sosialnya" 5 . Oleh karena itu, dalam beberapa kontribusi wisata budaya dibawah ini akan diulas secara umum terkait pemberian wisata budaya terhadap kesejahteraan masyarakatnya, antara lain:

\section{Peningkatan Ekonomi dan SDM}

Seperti yang sudah dijelaskan sebelumnya bahwa
kesejahteraan tidak hanya mencakup satu bidang saja, namun kesejahteraan seringkali diukur dari seberapa jauh perkembangan dan pendapatan ekonomi yang dapat dirasakan oleh masyarakat setelah adanya sebuah lembaga (pariwisata) sebagai sebuah sistem baru di lingkungan masyarakat, walaupun secara jelas bahwa hal ini juga tidak bisa dinafikan, karena material juga termasuk salah satu kategori dalam kesejahteraan. Hal ini dapat terlihat dari aktivitas masyarakat suku sasak Sade yang kalau di garap dari rentetan sejarah kehidupan sebelumnya, secara keseluruhan masyarakatnya hanya berprofesi sebagai petani dan mengais rizki melalui bercocok tanam, sehingga dalam pemenuhan kebutuhan fisik hanya bertumpu pada apa yang dihasilkan dari kegiatan tersebut. Namun dengan adanya wisata, masyarakat suku sasak Sade kini dapat memanfaatkan sektor pariwisata sebagai ajang untuk memperkenalkan produk-produk khas seperti kain tenun dan berbagai macam aksesoris bercirikan budaya sade dengan mengembangkan dan memberikan jasa penjualan seperti adanya tempat-tempat penjualan yang secara kepemilikan dimiliki oleh masyarakat suku sasak Sade disamping masyarakat Sade juga tetap melakukan aktivitas bercocok tanam sebagai pekerjaan yang paling diutamakan, dan sebagai tambahan penghasilan, mereka juga dapat

${ }^{5}$ Miftachul Huda, Pekerja Sosial \& Kesejahteraan Sosial, (Bandung: Pustaka Pelajar, 2009), hlm. 73. 
menghasilkan pendapatan melalui penawaran produk kepada setiap pengunjung yang datang, sehingga bisa dikatakan bahwa, pendapatan masyarakat Sade sebagiannya bertumpu pada jumlah wisatawan yang datang berkunjung.

Wisatawan memiliki peran penting dalam peningkatan pendapatan masyarakat lokal, sebab umumnya sebuah destinasi tidak bisa terlepas dari peran dan keberadaan pengunjung, terlebih lagi para pengunjung bisa menjadi konsumen utama keindahan dan kemewahan alam serta produk yang dihasilkan, juga para pengunjung bisa memposisikan diri sebagai donatur dalam mempercepat pengaplikasian dari upaya rencana yang ingin dicapai oleh lembaga wisata. Maka tingkat jumlah pengunjung juga memiliki peran sangat penting dalam suatu pencapaian perbaikan taraf hidup masyarakat dalam sektor pariwisata dan memiliki pengaruh dan dampak besar yang bisa dibuktikan dari hasil rekapitulasi data pengunjung yang setiap tahun memiliki perubahan sebagai komparasi tingkat kesejahteraan dalam bidang ekonomi.

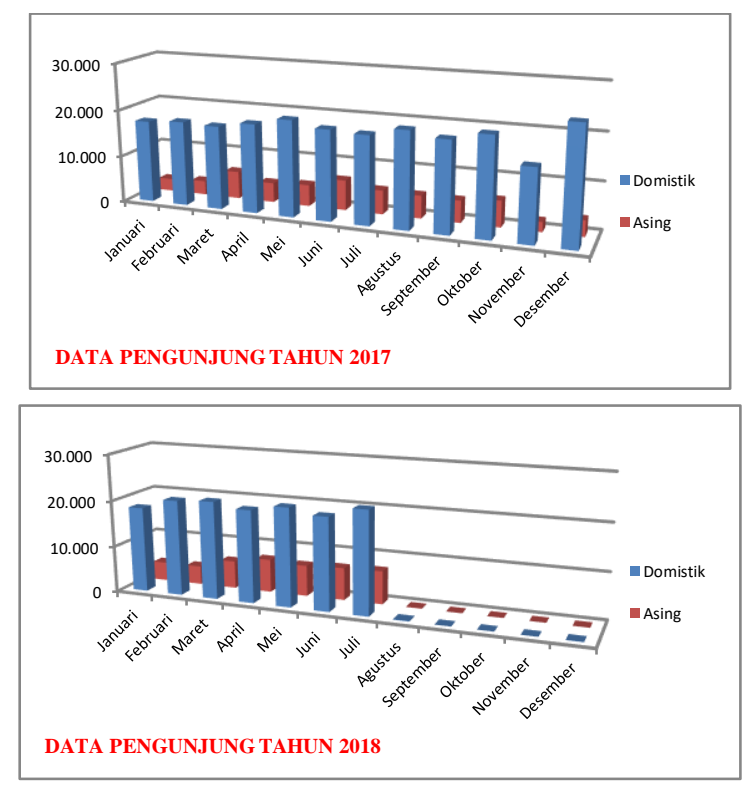


Grafik 1. Data Rekapitulasi Pengunjung Wisata Dusun Sade.

Hukum ekonomi akan terdengar lugas jika mengatakan "semakin banyak pengunjung yang datang, maka semakin besar kemungkinan pendapatan yang akan dihasilkan" dalam konteks konsep rekreasi dari sebuah destinasi wisata yang menyediakan barang tawaran dan jualan. Dari sisi lain, bisa juga dianalisis dari realita gejala alam yang tidak normal berupa gempa bumi pada bulan Agustus 2018 yang menimpa pulau lombok, ini menjadi salah satu faktor yang menyebabkan penurunan secara drastis terhadap jumlah pengunjung, dan karena keadaan itu, masyarakat suku sasak Sade mengalami masa krisis dalam perekonomian seperti grafik di atas sebagai indikator dari sejauh mana tingkat pencapaian kesejahteraan telah dialami masyarakat. Oleh karena itu, hal ini membuktikan bahwa normalnya peningkatan pendapatan masyarakat lokal dengan keberadaan wisata tersebut sangat dirasakan dari sisi perekonomiannya.

Selain dari segi ekonomi, pengembangan sumber daya manusia juga sangat terlihat di dusun Sade, terbukti pada keratifitas yang muncul, mulai dari hasil-hasil kerajinan baru masyarakat yang juga bisa ditawarkan kepada para pengunjung wisata, juga terbukanya peluang kerja bagi masyarakat lokal yang bisa dirasakan walaupun hanya sebagai pemberian jasa dalam bentuk sebagai seorang pemandu (guide) wisata. Maka peluang kerja-pun terbuka disebabkan karena keberadaan wisata ini. destinasi wisata budaya dusun Sade lebih mengedepankan masyarakat lokal sebagai pelaku inti dalam segala bentuk aktivitas dan pengelolaannya, walaupun bisa dikatakan secara persentase masih jauh tidak sebanding antara jumlah penduduk dengan jumlah tenaga wisata yang termasuk dalam struktur 
kelembagaan wisata di luar usaha otonom yang didirikan oleh masyarakat seperti tempat penjualan produk hasil kerajinan tangan. Namun dalam konteks sekarang ini lebih ditonjolkan kearah SDM-nya, artinya apa, tidak peduli jika seluruh jumlah penduduk Sade 46\%, sedangkan hanya $7 \%$ dari masyarakat lokal yang menjadi tenaga wisata berdasarkan data pesentase data sensus tahun 2017 dan temuan dilapangan. Sehingga kalau kita lihat dari segi persentase atau jumlah dalam bentuk hitungan matematika, maka kita akan menganggap bahwa kesejahteraan belum bisa terwujud dan dikategorikan sebagai masyarakat sejahtera, artinya wisata Sade belom bisa meraih itu semua. Namun, tingkat kesejahteraan tidak di hitung menggunakan rumus matematika (tambah, bagi dan kurang) yang hanya melihat kesejahteraan sebagai setengan atau 50\% dari jumlah keseluruhan angka, tetapi kesejahteraan dilihat dari kemampuan memanfaatkan sumber daya manusia penghuni wilayah asli sebagai pengelola dan pelaku aktif dalam segala aktifitas walaupun jumlahnya masih minim dan sedikit yang masuk di kelembagaan pengurus wisata, namun samasama memiliki tujuan untuk mendatangkan dan menawarkan jasa pemandu dengan dilengkapi berbagai produk yang bisa dibeli oleh pengunjung sebagai oleh-oleh atau sebagai testimony atas pernahnya berkunjung ke Dusun Sade. Lebih jelasnya kesejahteraan dalam konteks ini adalah melihat wisata budaya Sade telah mampu memberikan kegiatan baru dalam mencari nafkah dan juga bisa mengabdikan diri dikawasan mereka sendiri tanpa harus mencari pekerjaan di luar sana, inilah yang membuktikan bahwa terbukanya dan pemanfaatan potensi masyarakat lokal sebagai pelaku wisata secara langsung. 


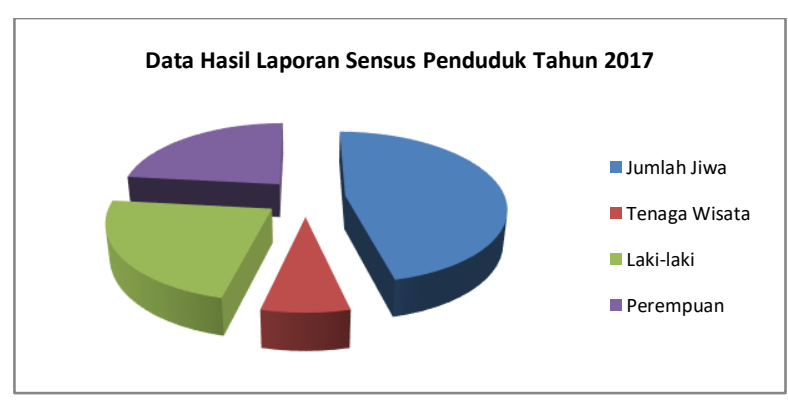

Grafik 2. Persentase Pemberdayaan SDM

Mulai dari pengelola wisata sampai pada pelayanan dan pelaksanaan wisata, dilaksanakan oleh masyarakat asli suku sasak Sade sendiri. Maka, dapat disimpulakn bahwa masyarakat suku sasak Sade dari segi ekonomi bisa dinikmati dan mengalami peningkatan seiring bertambahnya jumlah pengunjung wisatawan, dan juga kalau dari segi sumber daya manusianya, masyarakat lokal dilibatkan secara langsung dalam segala bentuk pengolahan dan pelayanan proses wisata dusun Sade, serta masyarakatnya dituntut untuk bisa berkreasi dalam segala hal, dan masyarakat lokal mengalami perkembangan dalam pelayanan, baik dari sisi etika, adab dan sopan santun serta mampu berkomunikasi menggunakan bahasa-bahasa asing sebagai bentuk pertama dari kontribusi wisata budaya terhadap kesejahteraan masyarakat.

\section{Terjalinnya Hubungan Sosial}

Kontribusi selanjutnya yang dihasilkan dari keberadaan wisata budaya ini untuk kesejahteraan dengan kategori selain ekonomi ialah menunjukkan kepada sisi sosialisme, yaitu sebagai makhluk sosial yang tidak bisa hidup dan luput dari bantuan orang lain, manusia pada hakikatnya diciptakan berpasang-pasangan, sebagaimana Allah S.W.T berfirman dalam kitab suci Al-Qur'an. Di antaranya: 


\footnotetext{
“Maha Suci Tuhan yang telah menciptakan pasangan-pasangan semuanya, baik dari apa yang ditumbuhkan oleh bumi dan dari diri mereka maupun dari apa yang tidak mereka ketahui".(Q.S. Yasin, 36)
}

Berpasang-pasangan tidak hanya diartikan sebagai hubungan antara laki-laki dan perempuan dalam ikatan suci, tetapi berpasangpasangan juga diartikan sebagai hubungan yang terjalin antar sesama makhluk yang saling membutuhkan antara makhluk yang satu dengan yang lainnya. Sehingga, menjadi salah satu kontribusi yang penting juga diberikan oleh wisata budaya Sade bagi masyarakat lokalnya yakni bisa mengembangkan jaringan dan hubungan baik dengan para wisatawan, tentu secara out put yang dihasilkan adalah proses interaksi yang baik akan menghasilkan hubungan yang baik pula, serta melalui hubungan yang baik inilah terbentuk hubungan sosiologis serta tali silaturrahmi akan tetap terjaga. Dalam hal kesejahteraan, menciptakan hubungan yang baik antara sesama juga dapat memberikan jalan untuk mewujudkannya. Sesuai dengan apa yang disabdakan oleh Rasulullah S.A.W dalam sebuah hadist yang berbunyi :
“Barang siapa yang ingin dilapangkan rizkinya dan dipanjangkan umurnya, maka hendaklah ia menyambung tali silaturrahmi”'(mutafaqun 'alaih) ${ }^{6}$

Menyambung tali silaturrahmi dapat melapangkan dan mempermudah pendapatan rizki dari segi ekonomi, dengan kata lain material akan terus berdatangan selama jalinan hubungan sosial yang

\footnotetext{
Syaikh Muhammad bin Shâlih al-'Utsaimîn, Betapa Penting Menyambung Silaturahmi,https://almanhaj.or.id/2658-betapa-penting-menyam-bung-silaturahmi.html, diambil tangga 2 April 2019, pukul 06.40 wita.
} 
baik tetap terjaga, lebih-lebih kalau hubungan itu terjalin atas dasar keberadaan wisata budaya yang sedang berkembang pesat. Kelebihan yang dihasilkan dari hubungan silaturrahmi ini sesuai dengan hadist di atas yakni, proses pencapaian kesejahteraan dari bidang ekonomi telah dijanjikan, semakin sering dan semakin banyak orang yang menjalin hubungan dengan mengunjungi secara langsung ke tempat wisata budaya Sade ini, maka tidak hanya keberkahan dunia yang didapatkan, tetapi juga mendapatkan keberkahan umur sebagai bentuk kesejahteraan sosial yang dapat dirasakan oleh masyarakat langsung karena setiap pengunjung adalah penyambung silaturrahmi sebagai sesama makhluk hidup dan soaial.

\section{Dapat Saling Mengenal (Budaya)}

Menurut McKercher dan du Cros dalam Tunggul Prasodjo, bahwa adanya perkembangan pariwisata budaya berkaitan erat dengan adanya apresiasi dari masyarakat untuk secara terus-menerus menjaga dan memelihara aset budaya atau pusaka budaya mereka yang dalam perkembangannya saat ini semakin dirasakan berkurang. ${ }^{7}$ Juga dalam referensi yang sama Goeldner mengemukakan bahwa pariwisata budaya mencakup semua aspek dalam perjalanan untuk saling mempelajari gaya hidup maupun pemikiran. Sehingga keberadaan wisata budaya dusun Sade, merupakan usaha mempertahankan, menjaga dan memelihara aset budaya yang sudah ditinggalkan untuk bisa selalu hidup dan dikembangkan oleh generasi selanjutnya. Disamping itu juga, kehadiran wisata budaya dusun Sade ini merupakan sebagai ajang untuk saling mempelajari budaya-budaya,

7 Tunggul Prasodjo, Pengembangan Pariwisata Budaya dalam Perspektif Pelayanan Publik, Vol, 3, No, 1, 2017, hlm. 9 
gaya hidup dan pemikiran masyarakat lokal sebagai pelaku, dan pengunjung sebagai pembelajar, sehingga kontribusi berikutnya ialah dari segi spiritual keberlansungan budaya yang ada dengan memberikan dan bertukar pengetahuan terhadap budaya di seluruh dunia.

Indonesia khususnya merupakan negara dengan begitu banyak ragam kebudayaan dan kekayaan sumber daya alamnya sehingga memungkinkan untuk bisa saling bertukar dan memperkenalkan budaya masing-masing dalam sebuah pertemuan secara langsung. Wisata budaya Sade yang kini juga menjadi salah satu destinasi wisata dalam bentuk budaya sebagai ajang untuk saling mengenal antar budaya. Sebagaimana keberagaman merupakan sebuah rahmat untuk bisa saling mengenal, seperti salah satu firman Allah S.W.T di bawah ini:

\footnotetext{
"Hai manusia, sesungguhnya Kami menciptakan kamu dari seorang laki-laki dan seorang perempuan dan menjadikan kamu berbangsa-bangsa dan bersuku-suku supaya kamu saling kenalmengenal. Sesungguhnya orang yang paling mulia diantara kamu disisi Allah ialah orang yang paling takwa diantara kamu. Sesungguhnya Allah Maha Mengetahui lagi Maha Mengenal". (Q.S. Al-Hujurat, 13)
}

keberagaman dapat di sebut sebagai sebuah keniscayaan yang merupakan rahmat bagi seluruh alam, namun esensi dari itu semua adalah dapat saling mengenal antara yang satu dengan lainnya, sehingga dalam aplikasi wisata juga bisa bermanfaat untuk penambahan wawasan dan dapat berbagi pengalaman. Seperti halnya wisata budaya dusun Sade yang memiliki kontribusi bagi masyarakat lokal dalam upaya meningkatkan kesejahteraan dapat dilihat dari 
pengenalan keberagamaan pada aktivitas wisata antara pengunjung dan masyarakat lokal, yakni selain pengunjung mengetahui budaya yang hidup di Sade, juga masyarakat lokal mendapatkan pengetahuan dan pengalaman budaya yang hidup di daerah pengunjung. Sehingga dengan kata lain, tidak hanya masyarakat suku sasak Sade yang mengenal para pengunjung, tetapi wisata budaya Sade terkenal dimana-mana, dan inilah yang menjadi modal perkembangan wisata dan peningkatan kesejahteraan masyarakat lokal seterusnya.

\section{Kesimpulan}

Mengungkap penomena kehidupan masyarakat pada era milenial yang selalu berubah-ubah seiring perkembangan zaman dan kemajuan sistem peradaban dunia yang layaknya mengikat manusia untuk terus ikut sebagai pemeran yang bersifat dinamis dan menuntut untuk terus bergerak maju. Dunia pariwisata telah melahap habis seluruh bidang kehidupan masyarakat, seolah-olah menjadi bagian penting dalam kehidupan dan aktifitas sehari-hari, sehingga budaya-pun terlahir dengan kemasan baru tanpa merusak sedikitpun nilai citra dari kebudayaan asli dengan tujuan kesejahteraan masyarakat dapat dihasilkan melalui keberadaan wisata yang bercirikan budaya sebagai salah satu destinasi dan pengembangan serta pemberdayaan Sumber Daya Manusia sebagai prioritas atas pemanfaatan Sumber Daya Alam yang dimiliki. Dari hasil pembahasan dalam tulisan ini menyimpulan bahwa ada tiga aspek penting di dalamnya, antara lain: Pertama Budaya merupakan kunci utama yang sudah final layaknya manusia, Kedua Wisata sebagai alternatif pencapaian layaknya kendaraan, dan Ketiga Kesejahteraan merupakan tujuan pemberhentian, sehingga dari tiga bagian ini harus saling melengkapi guna mempercepat pencapaian. 
Namun sebelum itu, dalam pencapaian yang disebut dalam konteks ini sebagai sebuah kontribusi, tentu belum bisa diketahui sebelum mengetahui peluang serta hambatanya. Sehingga dalam pencapaian kesejahteraan melalui keberadaan wisata budaya Sade juga memiliki peluang dan hambatan, antara lain: Pertama, Peluang yang dimiliki oleh wisata budaya Sade ini ialah letak geografis yang cukup strategis untuk pengembangan wisata, juga mendukung untuk memunculkan budaya lama sebagai daya tarik baru bagi wisatawan, dan memiliki potensi besar untuk kehidupan masyarakatnya. Kedua, Hambatan yang dihadapi oleh wisata budaya Sade ini ialah langkanya bahan arsitektur yang digunakan sebagai pemertahan ciri khas budaya seperti ilalang yang digunakan sebagai atap bangunan, juga antisipasi atas kehawatiran pengaruh budaya Western yang sewaktu-waktu dapat merasuki pola fikir dan tingkah laku dari generasi-generasi penerus, yang akan menyebabkan hilangnya rasa cinta terhadap budaya sendiri yang telah di wariskan oleh leluhurnya karena terlalu terobsesi dan terlena dengan gaya hidup dunia modern.

Sedangkan kontribusi wisata budaya Sade untuk kesejahteraan masyarakat yakni dapat dilihat dari transformasi propesi mulai dari petani sampai kepada pengelola dan pemeran wisata yang dapat rasakan melalui peningkatan pendapatan atau peningkatan ekonomi serta pemberdayaan masyarakat lokal sebagai pelaku utama dalam seluruh rangkaian aktifitas wisata, juga dari segi sosial jaringan interaksi dan hubungan emosional dapat terjalin sebagai bentuk penyebaran silaturrahmi antar sesama, serta dengan keberadaan wisata budaya Sade ini sebagai ajang untuk menambah wawasan pengetahuan pengalaman dari berbagai budaya-budaya yang hidup di luar wilayah Sade, baik itu dari segi bahasa, tata cara berkomunikasi dan juga 
berperikalu. Sehingga secara simple kesejahteraan sosial masyarakat Dusun Sade tergolong sebagai masyarakat yang sejahtera berdasarkan pengertian dan pemahaman atas multi akses pencapaian kesejahteraan yang mencakup material, spiritual dan sosial sebagai awal pengembangan diri, perbaikan taraf hidup sehingga dapat melaksanakan fungsi sosialnya .

\section{Daftar Pustaka}

M. Liga Suryadana \& Vanny Octavia. (2015). Pengantar Pemasaran Pariwisata. Bandung; Alfabeta

Elly M. Setiadi. Dkk. (2008). IImu Sosial Dan Budaya Dasar. Jakarta: Kencana Prenada Media

Janianton Damanik. (2013). Pariwisata Indonesia Antara Peluang \& Tantangan. Yogyakarta: Pustaka Pelajar

Miftachul Huda. (2009). Pekerja Sosial \& Kesejahteraan Sosial. Bandung: Pustaka Pelajar

Syaikh Muhammad bin Shâlih al-'Utsaimîn, Betapa Penting Menyambung Silaturahmi,https://almanhaj.or.id/2658-betapapenting-menyam-bung-silaturahmi.html.

Tunggul Prasodjo. Pengembangan Pariwisata Budaya dalam Perspektif Pelayanan Publik, Vol, 3, No, 1, 2017, hlm. 9 https://ojs.unm.ac.id/jo/article/view/3448. 